\title{
PERGUMULAN ISLAM DAN BUDAYA JAWA DI LERENG GUNUNG MERBABU PERSPEKTIF DAKWAH
}

\author{
Ahmad Faqih \\ Universitas Islam Negeri (UIN) Walisongo Semarang \\ Email: faqih.walisongo@gmail.com
}

\begin{abstract}
Pakis people who live at the valley of Mount Merbabu is the representative of syncretic Javanese Muslims. As Muslims, they carry out the Islamic shari'ah. But as Javannese people, they perform Javanese cultural traditions such as shamanism. They practice it as a way to solve their life problems, such as to cure diseases, to find lost things, and to win the competition in the selection of certain positions. By using a qualitative approach, the study found a character positive change as a result of consistently da'wah efforts by the preachers. They have implemented a kind of cultural da'wah, as a strategy to encourage the society to change their shamanism tradition gradually. The preachers realize that this tradition is dominant in the society, so that if they used a structural strategy of da'wah, social upheavals could happen among the society in which finally would fail the da'wah mission.
\end{abstract}

$* * *$

Masyarakat Desa Pakis yang hidup di kaki Gunung Merbabu, merupakan reperesentasi umat Islam Jawa dengan karakter sinkretik. Mereka beragama Islam dan menjalankan syari'at-Nya, tetapi sebagai orang Jawa mereka melaksanakan tradisi dan budaya Jawa seperti perdukunan. Perilaku berdukun dilakukan masyarakat untuk menjalani kehidupan sehari-hari dan cara untuk menyelesaikan problem yang mereka hadapi. Seperti usaha untuk menyembuhkan penyakit, mencari benda-benda yang hilang, memenangkan persaingan dalam pemilihan jabatan tertentu. Dengan pendekatan kualitatif, penelitian ini menemukan gejala perubahan karakter itu yang positif sebagai hasil nyata dari upaya dakwah yang dilakukan secara konsisten dan berkesinambungan.Para da'i menerapkan dakwah kultural, sebagai strategi untuk mendorong perubahan perilaku masyarakat dari berdukun secara perlahan. Da'i juga menyadari bahwa budaya berdukun cukup dominan di masyarakat,sehingga jika digunakan strategi struktural dikhawatirkan akan menimbulkan kegoncangan sosial di masyarakat. Pada akhirnya dakwah yang dilakukan akan menemukan kegagalan.

Keywords: Javanese Islam, Shaman, da'wah 


\section{A. Pendahuluan}

Pergumulan Islam dan budaya Jawa melalui pendekatan Islamisasi Jawa dan Jawanisasi Islam masih menyisakan sejumlah persoalan. Melalui proses yang damai tanpa ketegangan dan konflik ${ }^{1}$, dalam rentang periode sejarah yang panjang dari generasi ke generasi, Islam sebagai pembawa nilai-nilai budaya baru yang agung, belum mampu menggantikan seluruhnya nilai-nilai budaya lama dibawah religi animisme-dinamisme maupun agama Hindu-Budha. Artinya orang Islam Jawa, pada satu sisi ia taat menjalankan doktrin-doktrin agama Islam, pada sisi lain ia juga taat menjalankan tradisi, ritual, keyakinan, dan nilai-nilai budaya Jawa yang ada kalanya bertentangan atau dilarang dalam ketentuan syari'at Islam.

Menurut Simuh2, warisan nilai-nilai budaya lama sampai masa transisi menuju modern, ilmu perdukunan dan jampi-jampi semakin semarak. Karena alam pikiran modern baru menyentuh lapisan minoritas kaum terpelajar saja. Praktik-praktik perdukunan dengan segala bentuk ritualnya, masih ditemukan di beberapa daerah di wilayah Jawa. Pada masyarakat perkotaan dan pedesaan, ketergantungan kepada dukun dapat dijumpai untuk memenangkan judi, melancarkan karir dalam berbagai bidang, pergantian kepala desa juga sarat dengan bentuk ritual dari perdukunan. Apalagi bagi masyarakat di daerah pegunungan, dimana masyarakat cenderung memegang tradisi leluhur. Sehingga kecenderungan ini menjadikan masyarakat "berkelamin ganda". Misalnya, sebagian umat Islam di lereng Gunung Tengger Jawa Timur, masih melakukan ritual adat agama lokal Tengger, praktik perdukunan, dan menjadikan dukun sebagai tokoh panutan dalam hal spiritualitas yang sangat dihormati. Karena masyarakat sangat percaya, dengan kepandaian seorang dukun segala niat, hajat dan permohonan keselamatan bisa disampaikan ${ }^{3}$.

Masyarakat di Desa Pakis Kecamatan Pakis Kabupaten Magelang masih mempunyai ketergantungan yang sangat kuat kepada dukun. Berbagai persoalan hidup sehari-hari seperti memulai bercocok tanam, meminta penglarisan berdagang, meminta pengasihan, meminta kelancaran dan kesuksesan meniti karier, meminta pengobatan dari penyakit, menemukan barang-barang yang hilang, selalu dikonsultasikan

1 Paisun, Makalah "Dinamika Islam Kultural (Studi atas Dialektika Islam dan Budaya Lokal Madura)", ACIS Ke-10, Banjarmasin 1-4 November 2010, hlm. 1.

${ }^{2}$ Simuh, Islam dan Pergumulan Budaya Jawa, (Jakarta: Teraju, 2003).

3 Setyo Boedi Oetomo, "Dinamika Agama Lokal Tengger di Tengah Perubahan Sosial" dalam Kumpulan Makalah Desiminasi Hasil Penelitian Tahap Kedua, (Semarang: Balitbang Agama Semarang, 2012), hlm. 99. 
kepada seorang dukun desa. Karena masyarakat percaya, dengan kemampuan magis yang dimiliki seoarang dukun, ia mampu memenuhi atau mengabulkan segala hajat yang diinginkan. Sehingga posisi dukun di masyarakat lereng Gunung Merbabu ini, menempati posisi yang terhormat, karena dukun dinilai paling berjasa dalam mengatasi problematika kehidupan mereka.

Sebagai bentuk akumulasi dari simbiosis mutualisme antara dukun dengan masyarakat menjadikan dukun sebagai tokoh yang disegani masyarakat. Apa yang dikatakan dukun, itu pula yang dilakukan oleh masyarakat, baik urusan pribadi, keluarga, politik dan bahkan agama. Jika dilihat dari jenis-jenis masalah yang dikonsultasikan kepada seorang dukun, maka mereka berasal dari berbagai latar belakang profesi antara lain petani, pedagang, karyawan swasta dan PNS.

Demikian juga dari segi latar belakang agama mereka yang berdukun, semua penganut umat beragama seperti Hindhu, Budha, Kristen, Islam Kejawen dan Islam masih menggantungkan urusan-urusan kehidupan mereka kepada dukun. Satu hal yang sangat ironis lagi, sebagian dari orang Islam yang berdukun notabenenya adalah tokoh-tokoh agama Islam.

Padahal Islam sebagai agama tauhid, mengajarkan manusia berketuhanan yang benar, dan menuntun manusia untuk berkemanusiaan yang benar pula. Dalam kehidupan sehari-hari tauhid seharusnya menjadi pegangan pokok yang membimbing dan mengarahkan manusia untuk bertindak benar, baik dalam hubungannya dengan hablum minallah dan hablum minannas serta alam semesta. Menjalankan tauhid yang benar, akan mengantarkan manusia menuju kebebasan asasi yang paling fundamental ${ }^{4}$. Karena watak dasarnya yang anti mitologi dan anti sakramentalisme, Islam merupakan agama yang bersifat langsung, lurus, wajar, alami, sederhana dan mudah dipahami. Hal ini yang menjadikan Islam mudah tersebar dan mengalami perkembangan yang cepat melebihi sejarah agama-agama di dunia. Secara khusus Majlis Ulama Indonesia (MUI) melalui fatwanya No.2/Munas VII/MUI/2/2005 tentang Perdukunan (kahanah) dan Peramalan ('irafah) memberi hukum haram kepada umat Islam yang melakukan, mempublikasikan, memanfaatkan dan atau mempercayai segala bentuk perdukunan dan peramalan.

Tulisan ini akan mendeskripsikan problem orang Islam berwajah ganda tersebut pada komunitas muslim di Jawa. Serta upaya dakwah

${ }^{4}$ Ahmad Amir Azis, dkk., Kekeramatan Makam (Studi Kepercayaan Masyarakat terhadap Kekeramatan Makam-Makam Kuno di Lombok), dalam Jurnal Penelitian Keislaman Vol.1 Desember 2004, hlm. 59. 
Islamiyah yang sebaiknya dilakukan untuk merekonstruksi bangunan kehidupan beragama yang benar, sesuai dengan cita ideal doktrin Islam.

\section{B. Islam Dan Budaya Lokal}

Islam sebagai sebuah agama, seharusnya tidak dipahami sebagai seperangkat doktrin dan sistem moral yang terpisah dari kehidupan manusia. Ia tidak mengandung nilai-nilai dalam dirinya, tetapi mengandung ajaran yang menanamkan nilai-nilai sosial kepada penganutnya. Sehingga ajaran agama merupakan elemen yang membentuk sistem nilai budaya ${ }^{5}$. Nilai-nilai agama dijadikan pedoman berbagai tindakan dan pola perilaku manusia, baik yang bersifat individual maupun kolektif. Dalam perkembangan berikutnya, nilai-nilai agama dikonstruk oleh para penganutnya menjadi nilai-nilai budaya yang dilakukan secara terus-menerus dan dilakukan sampai lintas generasi (sebagai tradisi). Fungsi yang lain, nilai-nilai budaya yang bersumber dari agama menjadi standar perilaku manusia yang harus dilakukan dan jika diabaikan mengakibatkan dijatuhkan sanksi sosial bagi pelakunya (sebagai adat).

Dengan demikian dapat dipahami, antara kebudayaan dan agama masing-masing memiliki simbol-simbol dan nilai tersendiri. Agama adalah simbol yang melambangkan nilai ketaatan kepada Tuhan. Kebudayaan juga mengandung nilai dan simbol supaya manusia bisa mempertahankan eksistensinya. Agama memerlukan sistem simbol atau agama memerlukan kebudayaan agama. Maka dialektika antara agama dan kebudayaan merupakan kebutuhan untuk saling mengisi, dan menyempurnakan. Agama memberikan spirit pada kebudayaan, sedangkan kebudayaan memberi kekayaan terhadap agama. Hal inilah yang terjadi dalam dinamika pergumulan Islam dan budaya lokal di nusantara ${ }^{6}$. Secara tegas, Geertz (1992) memahami agama sebagai sistem kebudayaan. Agama memuat sistem simbol-simbol yang berlaku untuk menetapkan suasana hati dan memotivasi yang kuat, merumuskan konsep-konsep mengenai suatu tatanan umum eksistensi dan memancarkannya dalam realitas kehidupan manusia.Sangat wajar, jika muncul varian-varian Islam yang berbeda dari negara asal Islam antara lain: Islam Jawa, Islam Madura, Islam Sasak, Islam Minangkabau, Islam Bugis, Islam Banjar. Dialog antara Islam dan budaya lokal, tidak berarti mengorbankan Islam dan menempatkan Islam kultural

5 Zamachjsari Dfofier dan Abdurrahman Wahid, "Penafsiran Kembali Ajaran Agama: Dua Kasus dari Jombang", dalam Prisma No. 03 (Jakarta: LP3ES, 1978), hlm. 27.

${ }^{6}$ Koentowijoyo, Muslim Tanpa Masjid (Bandung: Mizan, 2001), hlm. 196. 
sebagai "Islam rendahan". Tetapi Islam kultural harus dilihat sebagai hasil dialektika antara Islam dengan budaya lokal baik dalam sisi akulturasi maupun asimilasi.

\section{Dakwah Islamiyah}

Dakwah adalah suatu ikhtiar yang dilakukan dengan berbagai cara untuk merubah pola pikir, sikap, dan perilaku mad'u agar sesuai dengan tuntunan ajaran Islam dalam rangka mencapai kebahagiaan di dunia dan di akhirat. Berbicara tentang metode, pendekatan mapun strategi tentu banyak pilihan yang bisa diputuskan oleh para da'i berdasarkan kondisi sosial mad'u yang dihadapi. Metode-metode yang tersedia diantaranya: ceramah, diskusi, dialog, propaganda, home visit, tanya jawab. Dari sisi pendekatan juga terdapat pilihan antara pendekatan structural dan pendekatan cultural. Demikian juga masalah stategi dakwah juga bisa strategi pemberdayaan, strategi rehabilitas sosial.

Salah satu pendekatan dan strategi dakwah adalah pendekatan structural, dengan merombak tatanan politik dan kehidupan masyarakat secara total dan mendasar dengan melakukan "pemaksaan" gagasan, ideologi agar tujuan yang diinginkan dapat tercapai. Pendekatan ini tentu saja dilatarbelakangi oleh suatu kondisi sosial tertentu. Kondisi dimaksud sudah diambang batas dengan kata lain kemungkaran dan kemaksiatan tidak dapat dikendalikan dan diatasi dengan cara-cara persuasive.

Pendekatan dakwah yang kedua adalah pendekatan cultural. Pendekatan ini misalnya dilakukan oleh para wali ketika berdakwah di tanah Jawa, terutama yang dilakukan oleh Sunan Kalijaga sebagai figure dakwah cultural. Ia memahami kearifan lokal dan mengoptimalkannya dalam usaha melakukan penyiaran Islam pada masyarakat Jawa. Salah satu kearifan masyarakat Jawa adalah hidup manusia akan berhasil sejauh ia berhasil menyesuaikan diri dengan realitas. Kriterium keberhasilan adalah suatu keadaan psikologis yaitu keselamatan, ketentraman batin yang tenang. Keadaan ini dapat tercapai jika seseorang memiliki sikap batin yang tepat ${ }^{7}$.Keberpihakan dakwah cultural adalah pada nilai-nilai universal kemanusiaan, menerima kearifan dan kecerdasan lokal, mencegah kemunkaran dengan memperhatikan keunikan manusia secara individual dan sosial.

7 Purwadi, Dakwah Sunan Kalijaga Penyebaran Agama Islam di Jawa Berbasis Kultural, (Yogyakarta: Pustaka Pelajar, 2005), hlm. 86. 


\section{Profil Desa Pakis}

Sebagaimana cerita para sesepuh desa, desa Pakis zaman dahulu merupakan hutan belantara yang membentang di lereng sebelah barat gunung Merbabu. Di dalam hutan terdapat beberapa sungai yang mengalir jernih berasal dari mata air gunung dan dari sumber-sumber mata air yang berada di sepanjang hutan. Air ini merupakan sumber bagi kehidupan ekosistem yang di hutan. Berbagai satwa hidup ada sebagai penghuninya. Harimau merupakan salah satu hewan buas yang dahulu pernah ada. Hingga saat ini hewan tersebut terkadang masih dapat dijumpai sebagaimana kera yang sampai saat ini masih hidup bebas di sekitar hutan di gunung. Berbagai pohon dan kayu hutan tumbuh dengan subur. Salah satu pohon yang banyak terdapat di hutan tersebut adalah jenis pohon pakis taji atau pakis haji.

Suatu saat datang seorang yang berasal dari kerajaan Demak. Ia adalah seorang yang sengaja mengasingkan diri dan menjauh dari keramaian kerajaan. Tujuannya menjauhkan diri dari kerajaan untuk mencari ketentraman hidup dan lebih mendekatkan diri kepada sang penguasa alam. Ada yang mengatakan bahwa ia mencari arti jatining diri dan menambah berbagai macam ilmu. Ia diberinama Kiswo Hardono atau ada juga yang menyebut Kisworo. Kiswo Hardono atau Kisworo ditemani beberapa 'penderek' atau pengikut yang telah membantunya sejak masih di Demak. Mereka adalah Mbah Burik dan Nyai Burik serta Mbah Tambang dan Nyai Tambang.

Berbekal kemauan keras dan kemampuan yang dimiliki Kiswo Hardono atau Kisworo dibantu pengikutnya mulai membabat hutan. Dimulailah dari tempat yang ditumbuhi tanaman pakis taji. Tujuan utamanya untuk tempat tinggal atau bermukim. Selanjutnya ia membuat lahan pertanian untuk bercocok tanam guna memenuhi kebutuhannya. Sambil terus bekerja dan berjuang Kiswo Hardono senantiasa mendekatkan diri kepada sang pencipta untuk memohon ilmu yang berguna bagi kehidupannya.

Keberhasilan Kiswo Hardono atau Kisworo membuka lahan pertanian, menarik perhatian penduduk di sekitar hutan tersebut. Mereka datang untuk berbagai kepentingan, ada yang menimba ilmu pertanian, ilmu 'kanogaran', dan meminta pertolongan untuk kesembuhan penyakit yang diderita. Seiring dengan berjalannya waktu, tempat atau pemukiman itu bertambah ramai dan menjadi sebuah perkampungan.

Sosok Kisworo di perkampungan itu sangat dihormati oleh warwa. Ia dihormati sebagai pendiri kampong dan sesepuh bagi warga. Kisworo 
menjadi tokoh bagi warga untuk meminta pertolongan dalam menyelesaikan berbagai masalah dalam kehidupan termasuk meminta pertolongan bagi kesembuhan penyakit yang diderita warga. "Pak Kis" adalah panggilan akrap yang sering digunakan warga untuk memanggil atau menyebut namanya.

Keberadaan "Pak Kis" sebagai tokohdan sesepuh desa mulai tersebar luas ke daerah sekitar. Banyak warga yang dating ke rumah "Pak Kis" meminta berkah untuk berbagai kepentingan. Seiring perjalanan waktu dank arena banyaknya warga yang dating ke "Pak Kis", maka pemukiman atau dusun tempat tinggal Kisworo Hardono atau Kisworo itu terbiasa disebut "Pakis" yang tidak lain adalah nama panggilan Kiswo Hardono atau Kisworo ${ }^{8}$ (Dokumen RPJMD Desa Pakis Tahun 2010-2014).

Desa Pakis merupakan Ibu Kota Kecamatan Pakis, menjadi pusat administrasi, pemerintahan, pendidikan dan pelayanan kesehatan bagi masyarakat Kecamatan Pakis. Desa ini terletak pada ketinggian $723 \mathrm{~m}$ di atas permukaan laut dengan iklim sejuk, suhu berkisar antara 18 sampai dengan 27 derajat culcius. Keadaan tanahnya subur sehingga merupakan daerah pengembangan pertanian tanaman pangan dan hortikultura. Desa Pakis juga merupakan jalur utama bagi wisatawan menuju obyek rekreasi wisata alam Kopeng. Sehingga berpotensi untuk pengembangan industri pariwisata.

Pendidikan masyarakat Desa Pakis masih perlu ditingkatkan, mengingat dari data yang ada menunjukkan bahwa pendidikan masyarakat desa ini tergolong masih rendah. Berikut data tingkat pendidikan masyarakat Desa Pakis tahun 2009:

Tabel 1

Pendidikan Masyarakat

\begin{tabular}{|l|l|c|}
\hline No & \multicolumn{1}{|c|}{ Tingkat Pendidikan } & Jumlah \\
\hline 1. & Tidak Tamat SD & 911 \\
\hline 2. & Tamat SD/Sederajat & 1294 \\
\hline 3. & Tamat SLTP/Sederajat & 590 \\
\hline 4. & Tamat SLTA/Sederajat & 382 \\
\hline 5. & D1/D2/D3 & 51 \\
\hline 6. & S1/S2 & 63 \\
\hline
\end{tabular}

Sumber: Data Umum Desa Pakis Tahun 2013

8 Dokumen RPJMD Desa Pakis Tahun 2010-2014. 
Sebenarnya fasilitas pendidikan yang ada di Desa Pakis tergolong cukup lengkap, yaitu mulai dari jenjang PAUD sampai tingkat SLTA. Tempat-tempat kursus juga ada di desa ini, termasuk Taman Pendidikan Al-Qur'an (TPQ) juga terdapat di seluruh dusun. Secara umum fasilitas pendidikan di Desa Pakis dapat dilihat pada tabel berikut:

\section{Tabel 2}

\section{Fasilitas Pendidikan di Desa Pakis}

\begin{tabular}{|l|l|c|l|}
\hline No. & Jenjang Pendidikan & Jumlah & \multicolumn{1}{c|}{ Keterangan } \\
\hline 1. & Play Group & 1 & \\
\hline 2. & Taman Kanak-Kanak & 3 & TK Pertiwi, TK PGRI, TK RA \\
\hline 3. & Sekolah Dasar & 2 & SDN Pakis dan SDN Krasak \\
\hline 4. & SLTP & 1 & SMP PGRI \\
\hline 5. & SLTA & 1 & SMA Islam Sudirman \\
\hline
\end{tabular}

Sumber: Data Umum Desa Pakis Tahun 2013

Masyarakat di Desa Pakis mayoritas beragama Islam (belum ada data statistik jumlah pemeluk agama), yang didukung oleh tempat ibadah seperti masjid dan musholla yang terdapat di semua dusun. Selain itu lembaga-lembaga pendidikan informal dan formal juga terdapat di desa ini (lihat tabel pendidikan). Menurut Kyai Khudhori, kehidupan keagamaan masyarakat Desa Pakis dapat dinilai harmonis baik interen umat beragama dan hubungan antar umat beragama. Hampir tidak ada kejadian-kejadian yang menonjol yang mengakibatkan retaknya hubungan intern dan antar umat beragama ${ }^{9}$. Potensi sumberdaya manusia umat Islam juga cukup memadahi, karena banyak warga lulusan pondok pesantren yang kembali hidup di masyarakat. Dari keterangan salah satu tokoh agama di Desa Pakis, terdapat 50 orang lulusan pondok pesantren yang saat ini menjadi guru-guru ngaji di Desa Pakis ${ }^{10}$.

\section{E. Tradisi Islam Jawa Di Desa Pakis}

Desa Pakis memiliki kekayaan tradisi yang berakar dari budaya jawa dan budaya Islam. Kedua akar budaya ini menjadi sumber lahirnya tradisi jawa, tradisi Islam, dan tradisi percampuran antara budaya jawa

\footnotetext{
9 Wawancara, 5 Nopember 2013.

10 Wawancara, 4 Nopember 2013.
} 
dan budaya Islam. Semua varian budaya tersebut hingga saat ini masih eksis dan menjadi tata nilai yang dianut oleh masyarakat Desa Pakis. Tradisi masyarakat tersebut antara lain:

1. Merti deso (slametan desa) atau Aum

Tradisi ini dilaksanakan oleh seluruh warga desa Pakis di dusun masing-masing dikoordinir oleh Kepala Dusun. Tradisi ini dimaksudkan sebagai bentuk syukur atas keberhasilan masyarakat dalam bercocok tanam, dilaksanakan setiap bulan rajab.

2. Nyadran bulan suro

Nyadran bulan suro dilaksanakan setiap tanggal 10 Muharram (minggu kliwon) dimaksudkan untuk memohon keselamatan dari segala bentuk malapetaka bagi masyarakat Desa Pakis. Tradisi ini dilaksanakan di suatu tempat khusus yaitu Gunung Balak di sebelah barat desa dan di petilasan Batur di pinggir jalan desa . Gunung Balak diyakini oleh masyarakat sebagai tempat 'petilasan' Syekh Subakir yang berjasa dalam menyebarkan Islam di tanah Jawah. Gunung Balak juga digunakan oleh sebagian masyarakat meminta pertolongan kepada Syekh Subakir atas segala hajat seperti meminta keberhasilan dalam bertani, berdagang, meniti karir, membangun rumah tangga, ikut pencalonan dalam jabatan politik dan pemerintahan dan lain-lain. Petilasan Batur, merupakan tempat yang dianggap keramat oleh warga desa. Karena di tempat itu terdapat kuburan tokoh desa yang berpengaruh pada jaman dulu yaitu Ismail.

3. Peringatan tahun baru hijriyah

Untuk mengenang jasa Syekh Subakir sebagian masyarakat Desa Pakis dan Desa Losari mengadakan kegiatan yang bernuansa Islam di Gunung Balak. Acara yang berlangsung di pagi hari setiap tanggal 1 Muharram, diawali dengan pembacaan tahlil dan do'a dilanjutkan siraman rohani oleh seorang kyai pemimpin Tarekat Naqsabandiyah. Jama'ah tarekat yang datang, berasal dari warga desa Pakis dan Losari serta dari daerah-daerah lain seperti Temanggung, Wonosobo, Pekalongan, Pemalang dan sebagainya.

4. Nyadran bulan ruwah

Tradisi nyadran bulan ruwah dilaksanakan setiap bulan ruwah atau sya'ban, untuk mengirim do'a kepada ahli kuburnya. Setiap keluarga membawa makanan dibawa ke balai desa, setelah membaca tahlil dan do'a kemudian makan bersama-sama di tempat tersebut.

5. Tradisi 'lacen'

Tradisi ini dimaksudkan untuk memberi makanan dan minuman dan kesenangan yang disukai oleh orang yang meninggal. Karena dipercaya 
oleh masyarakat arwah dari orang yang meninggal dalam kurun waktu 7 hari masih datang dan pergi ke rumah. Tradisi 'lacen' dilaksanakan pada hari dimana seseorang itu meninggal dunia. Makanan dan minuman yang disajikan seperti kopi, jadah baaakar dan rokok.

6. 'Ngruwat'

'Ngruwat' adalah tradisi masyakat yang diperuntukkan bagi suatu keluarga yang mempunyai anak satu ('ontang-anting'), anak tiga (anak pertama laki-laki, anak kedua perempuan dan anak ketiga laki-laki) atau disebut 'sendang kapit pancuran', anak tiga (anak pertama perempuan, anak kedua laki-laki, anak ketiga perempuan) atau disebut 'pancuran kapit sendang'. Dengan tradisi 'ngruwat' biasanya dengan mengadakan pementasan wayang kulit semalam penuh, dengan harapan keluarga yang memiliki anak tersebut akan diberi kebahagiaan, kesuksesan, dan dijauhkan dari malapetaka yang kelak bisa menimpa mereka jika tidak dilaksakan tradisi 'ngruwat'. Pementasan wayang untuk prosesi ngruwat membutuhkan persiapan yang lebih berat, misalnya dalang yang akan memimpin pementasan harus melakukan puasa 'nglapus' (tidak makan, tidak minum, dan tidak tidur selama tiga hari berturut-turut). Lakon pementasan wayang juga tidak sembarangan, seperti pementasan wayang pada umumnya.

7. Tahlilan orang meninggal

Tradisi pembacaan tahlil dilakukan selama 7 hari berturut-turut untuk warga yang meninggal. Sore hari memanjatkan do'a di makam orang yang meninggal, dan malamnya memanjatkan do'a di rumah/shohibul musibah. Selanjutnya tahlilan dilakukan pada hari ke-7, ke-40, ke-100, satu tahun atau 'mendak' dan ke-1000, serta setiap tanggal kematian.

8. Pengajian mingguan dan selapanan

Tradisi ini merupakan tradisi yang berkembang di Desa Pakis setelah agama Islam tersebar dan dianut oleh masyarakat. Pengajian mingguan dan selapanan dilaksanakan setiap satu minggu sekali dan setiap 35 hari sekali. Pengajian biasanya diawali dengan pembacaan tahlil, do'a, siraman rohani oleh kyai setempat bertempat di rumah-rumah warga secara bergiliran.

9. Mauludan

Tradisi mauludan dilaksanakan setiap bulan rabiul awal, untuk memperingati kelahiran Nabi Muhammad saw. Tradisi ini diisi dengan pembacaan kitab al-barjanji, dan pengajian akbar.

10. Syawalan

Syawalan merupakan tradisi Islam yang berintikan kegiatan warga Desa Pakis untuk saling member maaf. Tradisi ini dilakukan dengan 
cara berkunjung ke rumah-rumah, baik tetangga maupun saudara terdekat dan jauh. Umat Islam di Desa Pakis setiap bulan syawal, setiap rumah menyediakan makanan dan minuman untuk menjamu para tamu yang akan berkunjung ke rumah mereka.

11. Tradisi siklus hidup

Masyarakat Desa Pakis juga melaksanakan sejumlah tradisi untuk memulai membangun rumah, mengadakan hajat perkawinan, hajatan khitanan, dan bercocok tanam serta tradisi kelahiran anak. Semua tradisi ini dilakukan untuk mengharap keselamatan, keberkahan, dan kebahagiaan dalam menjalani hidup di dunia.

\section{F. Peran Dukun Dalam Kehidupan Masyarakat Pakis}

Masyarakat Pakis sebagai bagian dari masyarakat Jawa pada umumnya, telah menjalani hidup dalam tradisi secara turun-temurun dalam waktu yang cukup lama. Dalam lingkaran tradisi itu, seorang dukun menjadi bagian tidak terpisahkan. Karena dukun menjadi perantara, pemimpin ritual, dan orang yang berjasa dalam membantu memecahkan problematika masyarakat baik secara individu maupun kolektif. Dukun dan warga desa merupakan soko guru, dalam upaya menjamin keberlangsungan hidup yang harmonis, tentram dan bahagia. Hubungan antara warga dan dukun dengan segala hal yang menyangkut perdukunan, menjadi sebuah tata nilai yang dipedomani oleh masyarakat desa.

Dukun adalah orang yang dihormati karena sikap sosialnya, sukarela membantu sesama tanpa mengharap imbalan atas jasa yang diberikan. Kehidupannya rata-rata sederhana, hal ini menunjukkan bahwa praktik perdukunan tidak menjadi sumber mata pencaharian. Mereka biasanya bekerja sebagai petani. Kebahagiaan dukun didapat ketika orang yang dibantu terkabul hajatnya, sembuh dari penyakitnya, tuntas permasalahan yang dukunan bukan sebagai mata pencahardihadapinya. Tetapi pengaruh dukun terbatas pada relasi antar indivdu, sedangkan secara komunal mulai berkurang atau hampir tidak ada. Karena dukun tidak menduduki posisi strategis di masyarakat Pakis seperti Kepala Desa atau selain itu.

Dampak sosial perdukunan di masyarakat Pakis ada dua yaitu tradisi berdukun menjadi tata nilai di masyarakat. Berdukun menjadi keharusan atau perilaku utama yang harus dikerjakan oleh setiap warga. Tidak berdukun berarti pembangkangan terhadap tata nilai yang berlaku di masyarakat. Kedua masyarakat cenderung memilih jalan pintas untuk 
menyelesaikan permasalahan yang mereka hadapi. Jalan ini tentu saja, berpotensi merugikan diri sendiri dan orang lain.

\section{G.Upaya Dakwah untuk Mengembalikan Aqidah Umat Islam Jawa}

Dakwah adalah sebuah upaya untuk mensosialisasikan ajaran Islam kepada para pemeluknya. Proses sosialisasi ini dapat dilakukan melalui berbagai agen sosial di masyarakat seperti keluarga, kelompok, lembaga pendidikan formal dan informal, media massa, dan masyarakat. Setiap agen sosial mempunyai peran penting dalam membentuk pribadi umat Islam, baik sebagai individu maupun kolektif. Keluarga merupakan agen sosial pertama, dimana seseorang mengenal ajaran Islam melalui ucapan, sikap dan tindakan kedua orang tuanya sejak kecil bahkan mulai di dalam kandungan. Dalam lingkungan keluarga yang religius, anak-anak dididik berkata-kata yang sopan, dilatih hormat kepada orang yang lebih tua, dan dibiasakan untuk melakukan tindakan-tindakan terpuji. Begitu seterusnya, ketika masuk usia remaja, dewasa, dan orang tua akan mendapatkan pendidikan sosial untuk menjadikan Islam sebagai way of life. Tentunya jika agen-agen sosial yang lain, mempunyai misi yang sama untuk membangun umat Islam yang kaffah. Sinergitas agen-agen sosial itu menjadi kunci kesuksesan mencapai tujuan bersama. Perbedaan nilai-nilai yang disosialisasikan kepada individu-individu akan berakibat terjadinya pertentangan antara nilai satu dan nilai lainnya. Sehingga meraka bisa menjadi frustasi, dan melakukan tindakan-tindakan di luar norma masyarakat. Hal ini merupakan letupan tarik-menarik antar nilai yang tidak mampu diadaptasi oleh individu-individu.

Masyarakat Pakis sejak lama hidup dalam pengaruh tiga tradisi yang cukup kuat, pertama tradisi Jawa. Tradisi Jawa telah menjadi identitas masyarakat Pakis, karena tradisi itu dilakukan secara terusmenerus dari generasi ke generasi. Tradisi Jawa juga banyak dipengaruhi oleh kepercayaan dan agama masyarakat Jawa pada masa lalu, seperti animisme, dinamisme, Hindu dan Budha. Kepercayaan animisme dan dinamisme berinti adanya pengakuan kekuatan-kekuatan gaib yang berasal dari tumbuhan, tempat-tempat keramat, benda-benda bertuah, hewan, roh leluhur, dan makhluk halus yang dapat mempengaruhi kehidupan manusia. Sehingga untuk mencapai keselamatan, ketenangan, dan kebahagiaan hidup, manusia harus meminta ijin dan bantuan kepada seluruh kekuatankekuatan tersebut. 
Menurut Romdlon, dkk., animisme adalah aliran (doktrin) kepercayaan yang mempercayai realitas (eksistensi, maujud) jiwa (roh) sebagai daya kekuatan yang luar biasa yang bersemayam secara mempribadi di dalam manusia, binatang, tumbuh-tumbuhan, dan segala yang ada di alam raya ini ${ }^{11}$.

Dengan kepercayaan ini muncul penyembahan pada ruh nenekmoyang. Penyembahan pada ruh ini akhirnya memunculkan tradisi dan ritual untuk menghormati ruh nenek-moyang. Penghormatan dan penyembahan biasanya dilakukan dengan sesaji dan selamatan. Tujuan ritual ini adalah sebagai wujud permohonan pada ruh leluhur untuk memberikan keselamatan bagi para keturunannya yang masih hidup. Seni pewayangan dan gamelan adalah ritual yang seringkali dijadikan sarana untuk mengundang dan mendatangkan ruh nenek-moyang. Dalan tradisi ritual ini, ruh nenek-moyang dipersonifikasikan sebagai punakawan yang memiliki peran pangemong keluarga yang masih hidup.

Sementara dinamisme atau dinamistik adalah doktrin kepercayaan yang memandang bahwa benda-benda alam mempunyai kekuatan keramat atau kesaktian yang tidak mempribadi, seperti pohon, batu, hewan, dan manusia.8 Dengan kata lain, sebagaimana dikatakan Alisyahbana (1977) kepercayaan masyarakat Jawa pra-Hindu Budha adalah keyakinan akan hal-hal ghaib (tidak terlihat), besar dan menakjubkan. Mereka menaruh harapan agar tidak diganggu oleh kekuatan tersebut, apalagi mencelakakannya.

Agama Hindu dan Budha juga mempunyai prinsip-prinsip yang serupa dengan kepercayaan animism dan dinamisme. Walaupun dua agama ini mumpunyai prinsip ketuhanan yang kuat, tetapi keyakinan kekuatan-kekuatan gaib, kurang lebih sama seperti penganut kepercayaan animism dan dinamisme. Mereka memuja roh-roh leluhur, mempercayai kekuatan benda-benda bertuah, meyakini tempat-tempat keramat. Meskipun di desa Pakis orang-orang yang sangat memegang teguh tradisi Jawa atau disebut orang kejawen, tidak mengelompok secara khusus. Tetapi kepercayaan itu diyakini oleh mayoritas warga desa yang beragama Islam dan non Islam ${ }^{12}$. Kondisi ini sesuai dengan hipotesa Baker, bahwa sebagai orang Jawa tetap memegang teguh agama asli Indonesia (animism dan dinamisme) meskipun mereka telah memeluk agama baru. hlm. 36, 43 .

${ }^{11}$ Romdhon dkk, Agama-Agama di Dunia (Yogyakarta: IAIN Sunan Kalijaga Press, 1986),

12 Wawancara dengan Suroso Sekdes Desa Pakis, 1 Nopember 2013. 
Kedua, tradisi Islam. Agama Islam di desa Pakis merupakan agama baru yang datang setelah agama Hindu dan Budha. Tetapi eksistensi agama Islam di daerah ini, juga semakin kuat seiring dengan kenyataan mayoritas warga Desa Pakis memeluk agama Islam. Masjid berjumlah 10 unit dan musholla 19 unit tersebar di semua dusun, termasuk ada beberapa dusun yang memiliki Taman Pendidikan Al Qur'an seperti di Pakis Tengah, Compok Kulon, Bowongan, Pakis Kidul, Krasak, Compok Wetan, Magersari, Plalar, Bentoyo, dan Kwiden Kecil. Kegiatan-kegiatan pengajian juga terdapat di semua dusun, seperti pengajian mingguan, pengajian selapanan dan kegiatan PHBI (Peringatan Hari Besar Islam). Kegiatan ini biasanya diserahkan kepada remaja desa, sedangkan orang tua mendukung dari belakang ${ }^{13}$. Berbagai tradisi Islam juga telah membudaya seperti mauludan, halal bihalal, dzibaan, tahlilan dan lain-lain.

Tetapi umat Islam di Desa Pakis, belum mempunyai kebersamaan dalam menjalankan ajaran Islam. Masjid dan musholla yang megah belum diimbangi dengan program kerja yang baik. Karena masjid dan musholla 'dimonopoli' oleh orang per orang yang didasari oleh egonya masingmasing14. "Masyarakat disini kalau berhubungan dengan masjid luar biasa (dalam arti gotong-royongnya). Tetapi belum sampai pada kebersamaan dalam memakmurkan masjid, keberagamaannya masih kalah dengan kemasyarakatannya".

Ketiga, tradisi Islam-Jawa. Sebagian masyarakat Pakis masuk dalam varian Islam sinkretik, meminjam istilah Simuh. Varian yang ketiga ini, menunjukkan kondisi psikologis warga pada satu sisi bersungguh-sungguh menjalankan ajaran Islam, tetapi disisi lain mereka masih mempertahankan tradisi Jawa yang sebagiannya bertentangan dengan syariat Islam itu sendiri. Peneliti tidak memperoleh data yang pasti tentang jumlah penganut varian ketiga ini. Tetapi dalam pengamatan peneliti selama di lapangan, varian ini memiliki penganut yang lebih banyak, jika dibandingkan dengan varian yang pertama (tradisi Jawa), dan kedua (tradisi Islam). Varian yang ketiga juga menjadi inti permasalahan yang ingin ditemukan jawabannya melalui proses penelitian. Karena tingkat pengetahuan mad'u tentang ajaran Islam dapat dikatakan di atas rata-rata, misalnya bagi mereka yang berlatarbelakang pesantren. Sementara mereka juga menjadi penganut fanatik tradisi Jawa, ada kalanya tidak sesuai dengan ajaran agama Islam atau bahkan bertolak belakang. Bruce Kapferer (Alhumami, 2010) mengatakan, kepercayaan kepada dukun

13 Wawancara dengan Suroso, 2 Nopember 2013.

14 Wawancara dengan Fathoni, 4 Nopember 2013. 
dan praktik perdukunan merupakan local beliefs yang tertanam dalam kebudayaan suatu masyarakat. Sebagai local beliefs, keduanya (dukun dan praktik perdukunan) tak bisa dinilainya diserahkan dari sudut pandang rasionalitas ilmu karena punya nalar dan logika sendiri yang disebut rationality behind irrationality. Orang yang kemudian mempercayai dukun dan praktik perdukunan tidak lantas digolongkan ke dalam masyarakat tradisional atau tribal, yang melambangkan keterbelakangan. Hal ini sejalan dengan pemikiran E.E. Evans Pritchard (Pals,2001), kepercayaan terhadap kekuatan supranatural itu tidak mengenal batasan sosial, seperti yang dia teliti pada Suku Azande di Sudan. Baginya, orang berpikiran modern, termasuk dirinya sekalipun, percaya terhadap kekuatan supranatural.

Para da'i di Desa Pakis lebih memilih jalan akomodatif terhadap tradisi Jawa yang bertentangan dengan syari'at Islam. Jalan ini dianggap paling memungkinkan untuk diterapkan di daerah Pakis. Menurut Bapak Fathoni, cara ini dianggap paling efektif untuk mengahapi kekuatan tradisi Jawa yang sudah "mendarah daging". Dakwah dengan cara kekerasan, justru berakibat da'i dikucilkan di masyarakat. Pada kondisi seperti ini da'i tidak mempunyai kesempatan untuk menyusun strategi dakwah yang lebih baik karena sudah terputus komunikasi dengan mad'u ${ }^{15}$. Jalur akomodatif juga diikuti oleh Kyai Khudhori, apabila orang masih melakukan tradisi Jawa/yang bertentangan dengan ajaran Islam dipersilahkan.

"Nanti kalau dilarang jadi tidak enak"16

Selain jalur akomodatif atau kultural, sebagian da'i juga menempuh jalur struktural. Bapak Fathoni menyadari mad'u dari kalangan orang dewasa dan orang tua sudah susah diajak untuk meninggalkan tradisi Jawa yang bertentangan dengan aqidah Islam. Maka sasaran dakwahnya diarahkan kepada remaja dan anak-anak dengan mendirikan yayasan pendidikan, saat ini membuka Madrasah Diniyah, RA, PAUD dan SDIT (Sekolah Dasar Islam Terpadu). Remaja dan anak-anak dinilai masih cukup "steril" dari tradisi kejawen . Sehingga mereka masih bisa diharapkan untuk lahir sebagai generasi baru Islam di desanya yang memiliki aqidah yang kokoh. Selain menempuh jalur struktural melalui pendirian lembaga pendidikan, ia membina umat Islam di desanya melalui pengajian rutin. Bahkan ia juga merambah politik praktis, sebagai Ketua Partai Golkar Kecamatan Pakis.

15 Wawancara dengan Fathoni, 4 Nopember 2013.

16 Wawancara dengan Kyai Khudhori, 5 Nopember 2013. 
Dakwah melalui jalur struktural di bidang politik, mempunyai posisi strategis untuk menegakkan kebenaran dan keadilan. Dalam pandangan M.Natsir kekuasaan pemerintah harus atas dasar kerelaan rakyat. Rakyat berhak patuh ketika pemimpin menjalankan kekuasaan secara benar. Pemerintah harus mengontrol kehidupan rakyatnya agar tidak terjadi pelanggaran. Selanjutnya pemerintah harus pula dikontrol oleh parlemen dan masyarakat. Sehingga pemerintah tidak menggunakan kekuasaan sewenang-wenang. Pemerintah harus menyediakan dirinya sebagai sasaran amar ma'ruf nahi munkar ${ }^{17}$.

\section{H. Kesimpulan}

Umat Islam di Lereng Gunung Merbabu tepatnya di desa Pakis, telah lama hidup dalam balutan tradisi jawa yang telah mengakar. Sejumlah tradisi yang bertentangan secara diameteral dengan keyakinan sebagai seorang muslim, juga hidup dalam harmoni yang turun-temurun.

Dakwah sebagai suatu ikhtiar untuk memisahkan tradisi-tradisi tersebut, mengalami berbagai kendala. Tetapi secara kualitas hasil-hasil yang dicapai menunjukkan kemajuan yang cukup berarti, meskipun harus menempuh jalur kultural (akomodatif) dengan resiko waktu perubahan lebih lama.

17 M.Natsir, Demokrasi di Bawah Hukum, (Jakarta: Dewan Dakwah, 1988), hlm. 12-15. 


\section{DAFTAR PUSTAKA}

Alhumami, Amich. Dukun dan Politik. Maret 5th, 2009 at 1:04 PM (serial online), diunduh 27 Agustus 2010

Amir Aziz, Ahmad, , dkk., "Kekeramatan Makam (Studi Kepercayaan Masyarakat terhadap Kekeramatan Makam-Makam Kuno di Lombok)", dalam Jurnal Penelitian Keislaman Vol.1 Desember 2004.

Boedi, Oetomo Setyo, "Dinamika Agama Lokal Tengger di Tengah Perubahan Sosial" dalam Kumpulan Makalah Desiminasi Hasil Penelitian Tahap Kedua, (Semarang: Balitbang Agama Semarang, 2012).

Dhofier, Zamakhsyari dan Abdurrahman Wahid, "Penafsiran Kembali Ajaran Agama: Dua Kasus dari Jombang", dalam Prisma No.03 (Jakarta: LP3ES, 1978).

Faqih, Ahmad, "Pergumulan Islam dan Budaya Lokal di Lereng Gunung Merbabu (Studi Identifikasi Masalah Perdukunan dan Upaya Dakwah Islam di Desa Pakis Kecamatan Pakis Kabupaten Magelang)", Laporan Penelitian, Fakultas Dakwah dan Komunikasi IAIN Walisongo Semarang Tahun 2013.

Geertz, Cliford, Abangan, Santri ,Priyayi, dalam Masyarakat Jawa, (Jakarta: Dunia Pustaka, 1983).

Koentowijoyo, Muslim Tanpa Masjid, (Bandung: Mizan, 2001).

M.Natsir, Demokrasi di Bawah Hukum, (Jakarta: Dewan Dakwah, 1988)

Pals, Daniel L, Dekonstruksi Kebenaran: Kritik Tujuh Teori Agama, terj. Inyiak Ridwan Muzir dan M. Sukri, (Yogyakarta: Ircisod, 2001).

Purwadi, Dakwah Sunan Kalijaga Penyebaran Agama Islam di Jawa Berbasis Kultural, (Yogyakarta: Pustaka Pelajar, 2005)

Simuh, Islam dan Pergumulan Budaya Jawa, (Jakarta: Teraju, 2003)

Dokumen:

Data Umum Desa Pakis Tahun 2013

Rencana Pembangunan Jangka Menengah (RPJM) Desa Pakis Tahun 20102014 